\title{
Use of on-farm data to guide treatment and control mastitis caused by Streptococcus uberis
}

\author{
Olivier Samson, ${ }^{*}$ Nicolas Gaudout, ${ }^{*}$ Ellen Schmitt, ${ }^{* 1}$ Ynte Hein Schukken, †‡ and Ruth Zadoks§\# \\ *Vetformance, 1 Rue Pasteur, 53700 Villaines la Juhel, France \\ †GD Animal Health, Arnsbergstraat 7, 7411 EZ Deventer, the Netherlands \\ łDepartment of Animal Sciences, Wageningen University, 6708 PB Wageningen, the Netherlands \\ \$Moredun Research Institute, Pentlands Science Park, Bush Loan, Penicuik, EH26 OPZ, United Kingdom \\ \#Institute of Biodiversity, Animal Health and Comparative Medicine, College of Medical, Veterinary and Life Sciences, University of Glasgow, \\ Glasgow G61 1QH, United Kingdom
}

\begin{abstract}
Treatment of mastitis is the most common reason for use of antimicrobial agents in dairy cattle. The responsible use of antimicrobials could be strengthened by knowledge of predictors for cure, which would help to tailor treatment decisions. Ideally, to allow for widespread uptake, this would be achieved using data that are routinely available. To assess whether this is feasible in practice, farmers were invited to submit milk samples from mastitis cases to their veterinary practice for bacteriological culture. Among 624 culture-positive samples, 251 were positive for Streptococcus uberis. Using cow-level data, cases were classified as severe, first nonsevere, repeat, or subclinical. Additional data were collected at the cow level [somatic cell count (SCC), parity, lactation stage, milk yield, fat and protein contents, treatment] and at the herd level (housing, bedding, premilking teat disinfection, postmilking teat disinfection). Severe cases were overrepresented among heifers and animals in early lactation, and repeat cases were overrepresented in cows with 3 or more lactations. The probability of cure was higher among first- and second-parity animals than among older cows, and was higher in animals with a single elevated cow-level SCC than in animals with multiple high SCC records. Results obtained in the current study are similar to those previously described for Staphylococcus aureus mastitis. Thus, routinely available cow-level information can help to predict the outcome of antimicrobial treatment of the most common causes of gram-positive mastitis.
\end{abstract}

Key words: mastitis, Streptococcus uberis, prognosis, antimicrobial treatment, clinical manifestation

Received January 29, 2016.

Accepted May 21, 2016.

${ }^{1}$ Corresponding author: ellen.vandeleemput@wanadoo.fr

\section{INTRODUCTION}

Antimicrobial resistance is increasingly perceived as a threat to human and animal health, and a range of national and international bodies (UK Department of Health, 2013; World Health Organization, 2015) have emphasized the need for the responsible use of antimicrobials. Key elements of the approach proposed by the World Health Organization include reduction of the incidence of infection and optimized use of antimicrobial medicines (World Health Organization, 2015). Farmers are increasingly aware of the need to use antimicrobials responsibly. In a recent survey in the UK, over $70 \%$ of dairy farmers said that reducing antibiotic usage would be "a good thing to do" (Jones et al., 2015). Veterinarians can play an important role in this process by providing information on ways to reduce antibiotic usage, such as minimizing the risk of disease or developing treatment protocols (Raymond et al., 2006; Jones et al., 2015).

On dairy farms, treatment of mastitis is a major reason for use of antimicrobials. For example, Pol and Ruegg (2007) calculated the estimated overall exposure to antimicrobial drugs of cattle on conventional dairy farms as 5.43 defined daily doses (DDD) per cow per year. This included 3.58 DDD of intramammary applications (2.02 DDD during lactation and 1.56 DDD at dry-off) and 1.85 DDD of parenteral use. Clinical mastitis (CM) was the most common reason for intramammary or parenteral antimicrobial usage. To reduce the use of antimicrobials, protocols for selective treatment of dry cows and cattle with CM have been developed, including protocols based on culture and on cow factors such as SCC (Lago et al., 2011; Cameron et al., 2014; Scherpenzeel et al., 2014). In culture-based protocols, treatment decisions are largely based on the distinction between gram-positive growth, gramnegative growth, and no growth (Lago et al., 2011; Cameron et al., 2014). Further refinement of treatment 
decisions may be possible when pathogen factors (such as antimicrobial resistance) and host characteristics (including duration of infection and parity) are taken into account, but this has been described in detail only for Staphylococcus aureus (Barkema et al., 2006).

In many countries on different continents, Streptococcus uberis is among the most common gram-positive causes of CM (Olde Riekerink et al., 2008; Petrovski et al., 2011; Verbeke et al., 2014). The organism is also responsible for a considerable proportion of subclinical mastitis cases (Bradley et al., 2007; Sampimon et al., 2009). Intramammary infections and CM caused by Strep. uberis can be transient, recurrent, or chronic, and a wide range of cure rates has been reported in response to treatment (Zadoks et al., 2003; Zadoks, 2007). Despite the importance of Strep. uberis as a mastitis pathogen, little is known about risk factors for the clinical manifestation or treatment outcome of Strep. uberis IMI. The aim of this study was to generate data that could inform low-cost guidelines for the improved management of Strep. uberis mastitis under field conditions. To that end, we conducted a farm-based study of herd- and cow-level risk factors associated with the clinical manifestation and likelihood of apparent cure of Strep. uberis IMI based on SCC. We used only tools and data that are routinely available to farmers and veterinary practices, including treatment and DHI records.

\section{MATERIALS AND METHODS}

\section{Milk Sampling and Bacteriological Culture}

From August 2012 until January 2014, quarter milk samples $(\mathrm{n}=624)$ were collected from French dairy cows with clinical or subclinical mastitis using standard aseptic sample collection methods (National Mastitis Council, 1999). Detection and sampling of mastitis cases was driven by participating farmers. To motivate farmers to participate in the study, all clients of our veterinary practice (Vetformance, Villaines la Juhel, France) with more than 50 lactating cows (approximately 500 farms) received an invitation to sample clinical and subclinical mastitis cases at their farms. The bacteriological analysis of the samples was free of charge for the farmers. In addition, upon return of completed data information sheets, a head collar for a cow was offered to the farmers. In total, 142 farmers submitted at least 1 milk sample, indicating an uptake of approximately $28 \%$.

Milk samples were subjected to bacteriological culture in the Vetformance laboratory. Aliquots of milk
$(10 \mu \mathrm{L})$ were plated onto 3 media: (1) Colombia blood agar containing $5 \%$ sheep blood (bioMérieux, Craponne, France; Ref. 43041); (2) colistin nalidixic acid (CNA) agar [blood agar plate containing $5 \%$ sheep blood, colistin $(10 \mathrm{mg} / \mathrm{L})$ and nalidixic acid $(15 \mathrm{mg} / \mathrm{L})]$ (bioMérieux; Ref. 43071) and (3) bromocresol purple (BCP) agar (bioMérieux; Ref. 43021). Plates were incubated at $37^{\circ} \mathrm{C}$ for 18 to $24 \mathrm{~h}$. Cultures were considered pure if only 1 morphotype was present on the blood agar plate. For pure cultures, growth on both the CNA and $\mathrm{BCP}$ plates was considered evidence that the bacteria were gram-positive; growth on only the BCP plate was evidence that the bacteria were gram-negative. Among gram-negative bacteria, Escherichia coli was characterized by a positive lactose reaction (color change of the BCP plate from purple to yellow) and a negative urea reaction (bioMérieux; Ref. 55752), whereas Klebsiella was identified by positive lactose and urea reactions. Gram-positive bacteria were considered Staph. aureus based on positive catalase and coagulase reactions (bioMérieux; Ref. 73112) and Staphylococcus spp. in the case of positive catalase and negative coagulase results. Identification of Strep. uberis was based on negative response in the catalase reaction and positive response in the esculin reaction (bioMérieux; Ref 42086; National Mastitis Council, 1999). Susceptibility to penicillin was also evaluated. This procedure increases specificity by excluding enterococcal isolates, which are more likely to be penicillin-resistant than streptococci (Makovec and Ruegg, 2003; Nam et al., 2010). Susceptibility to penicillin was tested using the disc diffusion method in accordance with the recommendations of the Société Française de Microbiologie (Soussy, 2013). Using a swab, a Mueller Hinton agar plate containing 5\% sheep blood (MH2, bioMérieux; Ref. 43321) was homogenously plated with a suspension of Strep. uberis at $0.5 \mathrm{McF}$ arland (equivalent to approximately $10^{8} \mathrm{cfu} /$ $\mathrm{mL}$ ). Plates were incubated at $37^{\circ} \mathrm{C}$ for 18 to $24 \mathrm{~h}$. Bacteria were considered sensitive to penicillin if they expressed a growth inhibition zone of more than $21 \mathrm{~mm}$

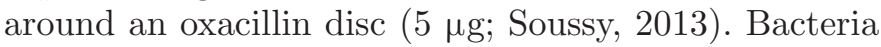
that could not be classified using the criteria described here were considered "other species."

\section{Cow and Herd Data}

Three data sources were used to obtain information about individual cows and their herds of origin: (1) private farm records on treatment, (2) monthly DHI data, and (3) questionnaires filled out by the farmer and the attending veterinarian. For each cow, the date of mastitis diagnosis (observation of CM or notification 
of SCC data via DHI) and treatment were recorded, including intramammary administration of antimicrobials, parenteral administration of antimicrobials, and use of nonsteroidal antiinflammatory drugs (NSAID). As well, DHI data were collected from the 3 milk recordings preceding the diagnosis of mastitis, the month of diagnosis, and the 3 recordings after diagnosis, if available. This included cow-level SCC data, parity $(1=$ first lactation, $2=$ second lactation, $3=$ third or higher lactation), DIM, milk yield $(\mathrm{kg})$, fat content $(\mathrm{g} / \mathrm{kg})$, and protein content $(\mathrm{g} / \mathrm{kg})$. At the herd level, information was collected on the use of premilking teat disinfection (PreMTD) and postmilking teat disinfection (PostMTD), use of housing (yes or no) and, where applicable, on housing type (cubicles or straw yards).

\section{Classification of Cases}

Clinical manifestation was classified into 4 categories based on the clinical severity of the current episode and information on previous episodes of $\mathrm{CM}$ in the same animal:

1. Severe: CM with both local and general symptoms (temperature $>39^{\circ} \mathrm{C}$ measured on clinical suspicion of fever by the farmers and results recorded on the data form accompanying the milk sample);

2. Nonsevere first case ("first"): first episode of CM during the current lactation, with local signs only (abnormalities of milk with or without abnormalities of the udder);

3. Nonsevere repeat case ("repeat"): second or subsequent episode of $\mathrm{CM}$ during the current lactation with local signs only in the current episode (abnormalities of milk with or without abnormalities of the udder); or

4. Subclinical: SCC $>200,000$ cells $/ \mathrm{mL}$ at the cow level based on most recent DHI data, not accompanied by any clinical signs.

For 212 of the 251 animals that tested positive for Strep. uberis, SCC data were partially available (fewer than 3 records before or after diagnosis) or complete (3 records before and after diagnosis). We used SCC data to classify the duration of inflammation before diagnosis and the response to treatment after diagnosis. Inflammation was considered "short" if at least 2 monthly SCC records before diagnosis were $<200,000$ cells/mL and "long" if at least 2 monthly SCC records before diagnosis were $>200,000$ cells $/ \mathrm{mL}$. An animal was considered cured if at least 2 monthly SCC after diagnosis were $<200,000$ cells $/ \mathrm{mL}$ and not cured if at least 2 monthly SCC after diagnosis were $>200,000$ cells $/ \mathrm{mL}$. For other SCC combinations or missing data, duration and cure were not determined (ND), such as for animals in early lactation or for cows that were dried off or culled before completion of follow-up.

\section{Statistical Analysis}

Statistical analyses were performed using Statistix, version 10 (Analytical Software, Tallahassee, FL). Data were inspected for outliers and missing values, and descriptive analyses were conducted using tabular and graphical formats. For outcomes of interest with 3 or more categories (e.g., for cow-level factors associated with clinical severity), data were analyzed using categorical methods (chi-square analyses). The association between clinical severity and milk, fat, or protein yield relative to occurrence of mastitis was evaluated using a $t$-test at each time point. To identify cow- and herdlevel risk factors for apparent cure based on SCC, we used logistic regression with backward stepwise analysis. The final logistic regression equation was

$$
\begin{gathered}
\text { Logit }(\text { SCC cure })=\text { intercept }+ \text { clinical manifestation } \\
+ \text { duration }+ \text { parity }+ \text { treatment }+ \text { error }
\end{gathered}
$$

where clinical manifestation was severe, first, repeat, or subclinical as defined above; duration was the inflammation history based on SCC (short, long, ND); parity was parity group $(1,2,3+)$; DIM was categorized as early, mid, and late lactation (<100, 100-200, 200+); and treatment was treatment for mastitis (intramammary antimicrobials, parenteral antimicrobials, NSAID, or no treatment). Two-way interactions between the main variables were also evaluated for statistical significance. No correction was made for clustering of cases within herd, because the model would not converge when herd was included due to the large number of herds and the limited number of cases per herd. We evaluated goodness of fit in the final model using model deviance and the Hosmer-Lemeshow statistic. In the Hosmer-Lemeshow statistic, the data are divided into 10 approximately equal deciles of observed risk. In these deciles, the observed and expected number of observation are compared using a chi-squared distribution with $10-2=8$ degrees of freedom (Hosmer and Lemeshow, 2013). A low value for the Hosmer-Lemeshow statistic indicates a good fit. A deviance value that is close to the remaining degrees of freedom implies no evidence of a poor fit. 


\section{RESULTS}

\section{Descriptive Analysis}

Of 624 milk samples submitted for culture, 251 (40\%) were positive for Strep. uberis in pure culture and 42 samples $(7 \%)$ were culture-negative. The remaining samples tested positive for $E$. coli $(\mathrm{n}=108$; $17 \%)$, Klebsiella $(\mathrm{n}=12 ; 2 \%)$, Staph. aureus $(\mathrm{n}=76$; $12 \%)$, Staphylococcus spp. $(\mathrm{n}=103 ; 17 \%)$, or other species $(\mathrm{n}=32 ; 5 \%)$. Samples positive for Strep. uberis originated from 142 farms. We obtained a single Strep. uberis-positive sample from 99 farms, and 2 or more Strep. uberis-positive samples from 20 and 23 farms, respectively. All isolates originated from cows with clinical or subclinical mastitis in 1 quarter with the exception of 3 cows, in which Strep. uberis was isolated from 2 quarters on the same sampling date. The clinical manifestation of Strep. uberis-positive mastitis cases was significantly different from the clinical manifestation of Strep. uberis-negative cases (chi-squared $=38.0$, $\mathrm{df}=3, P<0.005$; Figure 1): Strep. uberis was overrepresented among non-severe first cases and underrepresented among subclinical cases. Distribution across parities was not different between Strep. uberis and other diagnoses (chi-squared $=1.56, \mathrm{df}=2, P=0.46$ ). During the first $100 \mathrm{~d}$ of lactation, Strep. uberis was less common than other diagnoses, but it was more common between 100 and 200 DIM (chi-squared $=10.13$, $\mathrm{df}=2, P<0.05)$. Milk yield, fat, and protein content were not different between Strep. uberis and non-Strep. uberis cases before infection (results not shown).

Cow-level data for Strep. uberis cases are summarized in Table 1. Severe and subclinical Strep. uberis cases were overrepresented in parity 1 compared to higher parities, but non-severe first cases were overrepresented in parity 2 and repeat cases were overrepresented in higher parities (chi-squared $=13.67, \mathrm{df}=6, P<0.05$ ). Severe cases were overrepresented in early lactation, but repeat cases were overrepresented in mid-lactation (chisquared $=13.02, \mathrm{df}=6, P<0.05$; Table 1 ). Treatment records were available for approximately $80 \%$ of severe, first, and repeat cases, and for $42 \%$ of subclinical cases (chi-squared $=22, \mathrm{df}=3, P=0.0001)$. When no treatment was recorded, we considered this to indicate that no treatment was administered. Intramammary antibiotics as the only treatment were used more commonly to treat non-severe first cases than severe, repeated, and subclinical cases; they were used more commonly in combination with parenteral treatment for repeat cases and subclinical cases (chi-squared $=31 ; \mathrm{df}=6, P$ $<0.0001$; Table 1$)$. The combination of intramammary and parenteral antimicrobials with antiinflammatory

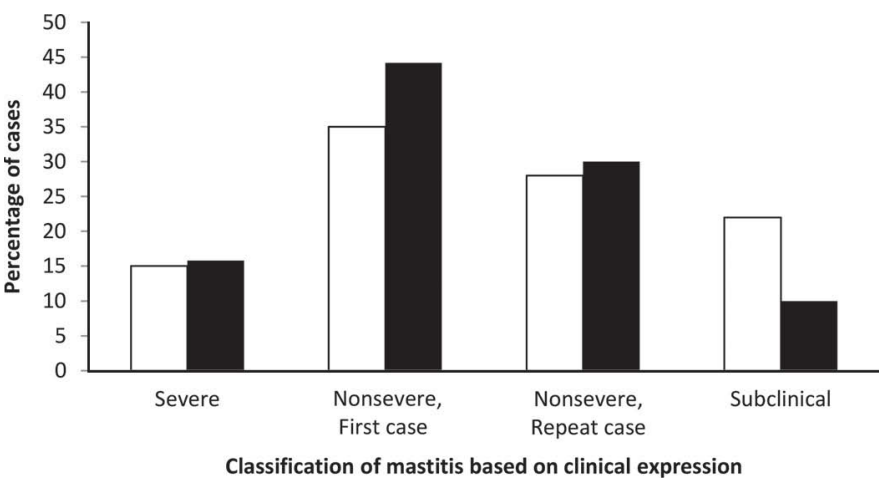

Figure 1. Clinical manifestation of mastitis for quarters with Strep. uberis-negative $(\mathrm{n}=373$, white) and Streptococcus uberis-positive (n $=251$, black) milk samples (chi-squared $=38.0, \mathrm{df}=3, P<0.005$ ). Severe $=$ clinical mastitis $(\mathrm{CM})$ with local and general symptoms (temperature $>39^{\circ} \mathrm{C}$, checked upon clinical suspicion of fever); nonsevere first case $=$ first occurrence of $\mathrm{CM}$ during the current lactation with local signs only (abnormalities of milk with or without abnormalities of the udder); nonsevere repeat case $=$ repeat occurrence of CM during the current lactation with local signs only during the current episode; subclinical $=$ elevated cow-level SCC $(>200,000$ cells $/ \mathrm{mL}$ based on DHI data) not accompanied by any clinical signs.

treatment was used mostly in severe cases and never for subclinical cases (Table 1). Milk production was numerically lower in severe cases than in non-severe cases, both before and after diagnosis of clinical or subclinical mastitis, with the exception of yield at $3 \mathrm{DHI}$ recordings before diagnosis, but the difference was not significant. No differences were detected between severity classes with regard to fat or protein content of milk before or after diagnosis of mastitis (data not shown).

Herd-level data from farms with Strep. uberis-positive results are presented in Table 2. Most herds were housed, either full-time or part-time. Straw yards were the predominant housing system; only $22 \%$ of herds were housed in cubicles. Almost all herds used PostMTD, and more than half of herds used both PreMTD and PostMTD; use of PreMTD without PostMTD was not reported. Severe cases were overrepresented in herds without PostMTD (chi-squared $=10.23, \mathrm{df}=3$, $P<0.05)$.

\section{Factors Associated with Cure of Strep. uberis IMI}

Cure was evaluated based on postdiagnosis SCC values, and results from the regression model are shown in Table 3. A total of 125 cases had complete data and were included in this analysis. Model deviance was 127.4 on $115 \mathrm{df}$; that is, the values were similar and showed no indication of a poor fit of the model to the data. The Hosmer-Lemeshow statistic was low 
(6.05), implying a good fit to the data. The probability of cure was significantly higher in animals in lactation 1 and 2 than in older animals. The probability of cure increased numerically with number of treatment types; that is, from no treatment to intramammary antimicrobials only to combined intramammary and parenteral antimicrobials, to both routes of antimicrobial administration combined with NSAID. However, we observed no statistically significant difference in cure between treatments. Finally, the probability of cure was higher in IMI with a short history of inflammation than in those with a long history of inflammation before treatment (Table 3). Clinical manifestation and herd-level variables were not associated with cure.

\section{DISCUSSION}

In this study, we aimed to use routinely available herd- and animal-level data to support control of Strep. uberis mastitis and the judicious use of antimicrobials. Risk factors for the incidence of Strep. uberis mastitis (CM or IMI) have been described at the herd level (Barkema et al., 1999; Ericsson Unnerstad et al., 2009) and animal level (Zadoks et al., 2001; Breen et al., 2009), and the effect of different treatment regimens on the outcome of treatment of Strep. uberis mastitis has been described for experimentally induced (Hillerton and Kliem, 2002; Oliver et al., 2003) and naturally occurring infections (Zadoks, 2007). To our knowledge,

Table 1. Cow-level data for Streptococcus uberis-positive mastitis cases, with breakdown by manifestation ${ }^{1}$

\begin{tabular}{|c|c|c|c|c|c|}
\hline \multirow[b]{2}{*}{ Cow factor } & \multirow{2}{*}{$\begin{array}{l}\text { All Strep. uberis } \\
\text { cases, no. }(\%)\end{array}$} & \multicolumn{4}{|c|}{$\begin{array}{l}\text { Strep. uberis cases by clinical } \\
\text { manifestation, no. }(\%)\end{array}$} \\
\hline & & Severe & First & Repeat & Subclinical \\
\hline \multicolumn{6}{|l|}{ DIM } \\
\hline$<100$ & $123(100)$ & $26(21)$ & $56(46)$ & $27(22)$ & $14(11)$ \\
\hline 100 to 200 & $63(100)$ & $7(11)$ & $25(40)$ & $27(43)$ & $4(6)$ \\
\hline$>200$ & $50(100)$ & $4(8)$ & $24(48)$ & $17(34)$ & $5(10)$ \\
\hline Subtotal & $236(100)$ & $37(16)$ & $105(44)$ & $71(30)$ & $23(10)$ \\
\hline \multicolumn{6}{|l|}{ Parity } \\
\hline First & $61(100)$ & $12(20)$ & $23(38)$ & $16(26)$ & $10(16)$ \\
\hline Second & $55(100)$ & $7(13)$ & $34(62)$ & $12(22)$ & $2(4)$ \\
\hline Higher & $122(100)$ & $17(14)$ & $49(40)$ & $44(36)$ & $12(10)$ \\
\hline Subtotal & $238(100)$ & $36(15)$ & $106(45)$ & $72(30)$ & $24(10)$ \\
\hline \multicolumn{6}{|l|}{ Treatment $^{2}$} \\
\hline None & 49 (100) & $7(14)$ & $17(35)$ & $12(24)$ & $13(27)$ \\
\hline IMM & $67(100)$ & $6(9)$ & $42(63)$ & $17(25)$ & $2(3)$ \\
\hline $\mathrm{IMM}+\mathrm{PAR}$ & $103(100)$ & $14(14)$ & $41(40)$ & $40(39)$ & $8(8)$ \\
\hline $\mathrm{IMM}+\mathrm{PAR}+\mathrm{NSAID}$ & $19(100)$ & $10(53)$ & $6(32)$ & $3(16)$ & $0(0)$ \\
\hline Subtotal & $238(100)$ & $37(16)$ & $106(45)$ & $72(30)$ & $23(10)$ \\
\hline \multicolumn{6}{|l|}{ Duration $^{3}$} \\
\hline Short & 78 (100) & $8(10)$ & $35(45)$ & $30(38)$ & $5(6)$ \\
\hline Long & $66(100)$ & $8(12)$ & $25(38)$ & $23(35)$ & $10(15)$ \\
\hline ND & $96(100)$ & $22(23)$ & $46(48)$ & $19(20)$ & $9(9)$ \\
\hline Subtotal & $240(100)$ & $38(16)$ & $106(44)$ & $72(30)$ & $24(10)$ \\
\hline \multicolumn{6}{|l|}{ Cure $^{4}$} \\
\hline Yes & 79 (100) & $10(13)$ & $39(49)$ & $23(29)$ & $7(9)$ \\
\hline No & $97(100)$ & $12(12)$ & $38(39)$ & $33(34)$ & $14(14)$ \\
\hline ND & $64(100)$ & $16(25)$ & $29(45)$ & $16(25)$ & $3(5)$ \\
\hline Subtotal & $240(100)$ & $38(16)$ & $106(44)$ & $72(30)$ & $24(10)$ \\
\hline
\end{tabular}

${ }^{1}$ Severe $=$ clinical mastitis $(\mathrm{CM})$ with local and general symptoms (temperature $>39^{\circ} \mathrm{C}$, checked upon clinical suspicion of fever). First $=$ first occurrence of CM during the current lactation with local signs only (abnormalities of milk with or without abnormalities of the udder). Repeat = repeat occurrence of CM during the current lactation with local signs only during current episode. Subclinical = cow-level SCC $(>200,000$ cells $/ \mathrm{mL}$ based on DHI data) not accompanied by any clinical signs.

${ }^{2}$ Treatment: IMM $=$ intramammary antibiotic treatment, PAR $=$ parenteral antibiotic treatment, NSAID = nonsteroidal antiinflammatory drug.

${ }^{3}$ Duration: short $=$ at least 2 monthly cow-level SCC $<200,000$ cells $/ \mathrm{mL}$ before diagnosis; long $=$ at least 2 monthly cow-level SCC $>200,000$ cells/mL before diagnosis; ND = not determined due to insufficient SCC data before diagnosis.

${ }^{4}$ Cure: yes $=$ at least 2 monthly cow-level SCC $<200,000$ cells $/ \mathrm{mL}$ after diagnosis; no $=$ at least 2 monthly cow-level SCC >200,000 cells/mL after diagnosis; ND = not determined due to insufficient SCC data after diagnosis. 
Table 2. Herd-level data for Streptococcus uberis-positive mastitis cases, with breakdown by manifestation ${ }^{1}$

\begin{tabular}{|c|c|c|c|c|c|}
\hline \multirow[b]{2}{*}{ Herd factor } & \multirow{2}{*}{$\begin{array}{l}\text { All Strep. uberis } \\
\text { cases, no. }(\%)\end{array}$} & \multicolumn{4}{|c|}{$\begin{array}{l}\text { Strep. uberis cases by clinical } \\
\text { manifestation, no. }(\%)\end{array}$} \\
\hline & & Severe & First & Repeat & Subclinical \\
\hline \multicolumn{6}{|l|}{ Housing } \\
\hline Permanent & $120(100)$ & $15(13)$ & $57(48)$ & 39 (33) & $9(8)$ \\
\hline Partial & $92(100)$ & $20(22)$ & $32(35)$ & $28(30)$ & $12(13)$ \\
\hline None & $28(100)$ & $3(11)$ & $17(61)$ & $5(18)$ & $3(11)$ \\
\hline Subtotal & $240(100)$ & $38(16)$ & $106(44)$ & $72(30)$ & $24(10)$ \\
\hline \multicolumn{6}{|l|}{ Bedding } \\
\hline Straw yard & $187(100)$ & $27(14)$ & $84(45)$ & $58(31)$ & $18(10)$ \\
\hline Cubicles & $53(100)$ & $11(21)$ & $22(42)$ & $14(26)$ & $6(11)$ \\
\hline Subtotal & $240(100)$ & $38(16)$ & $106(44)$ & $72(30)$ & $24(10)$ \\
\hline \multicolumn{6}{|l|}{ Predipping } \\
\hline Yes & $130(100)$ & $19(15)$ & $56(43)$ & $44(34)$ & $11(8)$ \\
\hline No & $106(100)$ & $18(17)$ & $48(45)$ & $27(25)$ & $13(12)$ \\
\hline Subtotal & $236(100)$ & $37(16)$ & $104(44)$ & $71(30)$ & $24(10)$ \\
\hline \multicolumn{6}{|l|}{ Postdipping } \\
\hline Yes & $214(100)$ & $29(14)$ & $94(44)$ & $67(31)$ & $24(11)$ \\
\hline No & $22(100)$ & $8(36)$ & $10(45)$ & $4(18)$ & $0(0)$ \\
\hline Subtotal & $236(100)$ & $37(16)$ & $104(44)$ & $71(30)$ & $24(10)$ \\
\hline
\end{tabular}

${ }^{1}$ Severe $=$ clinical mastitis $(\mathrm{CM})$ with local and general symptoms (temperature $>39^{\circ} \mathrm{C}$, checked upon clinical suspicion of fever). First $=$ first occurrence of CM during the current lactation with local signs only (abnormalities of milk with or without abnormalities of the udder). Repeat = repeat occurrence of CM during the current lactation with local signs only during current episode. Subclinical = cow-level SCC $(>200,000$ cells $/ \mathrm{mL}$ based on DHI data) not accompanied by any clinical signs.

Table 3. Logistic regression of cow factors versus cure for 125 cases of Streptococcus uberis mastitis

\begin{tabular}{|c|c|c|c|c|c|}
\hline Variable & $\begin{array}{l}\text { Coefficient } \\
\text { (SE) }\end{array}$ & $\begin{array}{l}\text { Odds } \\
\text { ratio }\end{array}$ & $\begin{array}{l}95 \% \text { CI for } \\
\text { odds ratio }\end{array}$ & Z-value & $P$-value \\
\hline Constant & $-4.8(1.3)$ & & & -3.68 & 0.0002 \\
\hline \multicolumn{6}{|l|}{ Parity } \\
\hline First & $1.7(0.6)$ & 5.5 & 1.8 to 5.5 & 3.1 & 0.0023 \\
\hline Second & $1.3(0.6)$ & 3.8 & 1.3 to 11.1 & 2.42 & 0.016 \\
\hline Third or higher & Base & & & & \\
\hline \multicolumn{6}{|l|}{ Clinical manifestation $^{1}$} \\
\hline Severe & $1.6(1.3)$ & 4.8 & 0.3 to 68.7 & 1.16 & 0.24 \\
\hline First & $2.0(1.2)$ & 7.1 & 0.7 to 77.0 & 1.65 & 0.10 \\
\hline Repeat & $1.9(1.2)$ & 6.4 & 0.6 to 70.9 & 1.54 & 0.13 \\
\hline Subclinical & Base & & & & \\
\hline \multicolumn{6}{|l|}{ Duration $^{2}$} \\
\hline Short & $1.7(0.5)$ & 3.1 & 2.2 to 14.2 & 3.74 & 0.0002 \\
\hline Long & Base & & & & \\
\hline \multicolumn{6}{|l|}{ Treatment $^{3}$} \\
\hline $\mathrm{IMM}+\mathrm{PAR}+\mathrm{NSAID}$ & $2.2(1.3)$ & 9.4 & 0.7 to 9.4 & 1.68 & 0.09 \\
\hline IMM + PAR & $1.1(0.6)$ & 3.1 & 0.9 to 3.1 & 1.79 & 0.074 \\
\hline IMM & $0.7(0.7)$ & 2.1 & 0.6 to 8.2 & 1.09 & 0.28 \\
\hline None & Base & & & & \\
\hline
\end{tabular}

${ }^{1}$ Severe $=$ clinical mastitis $(\mathrm{CM})$ with local and general symptoms (temperature $>39^{\circ} \mathrm{C}$, checked upon clinical suspicion of fever). First $=$ first occurrence of CM during the current lactation with local signs only (abnormalities of milk with or without abnormalities of the udder). Repeat $=$ repeat occurrence of CM during the current lactation with local signs only during current episode. Subclinical $=$ cow-level SCC $(>200,000$ cells $/ \mathrm{mL}$ based on DHI data) not accompanied by any clinical signs.

${ }^{2}$ Duration: short $=$ at least 2 monthly cow-level SCC $<200,000$ cells $/ \mathrm{mL}$ before diagnosis; long $=$ at least 2 monthly cow-level SCC $>200,000$ cells $/ \mathrm{mL}$ before diagnosis.

${ }^{3}$ Treatment: IMM $=$ intramammary antibiotic treatment, PAR $=$ parenteral antibiotic treatment, NSAID $=$ nonsteroidal antiinflammatory drug. 
animal-level risk factors for severity of disease or treatment outcome of Strep. uberis IMI have not been described. Here, we show for the first time that animallevel data can be used to predict the outcome of antimicrobial treatment for Strep. uberis mastitis and to guide treatment decisions. Specifically, the probability of cure was higher among first- and second-parity animals compared with older cows, and in animals with, at most, a single elevated cow-level SCC before diagnosis compared with those with multiple high SCC records. Those findings are strikingly similar to results obtained for Staph. aureus IMI across a range of studies covering both clinical and subclinical mastitis (Barkema et al., 2006) and can be used to inform decisions about treatment duration or the choice between treatment and culling. The individual making treatment decisions will be able to weigh these factors and use this information to provide a realistic prognosis. Pathogen-specific predictors for cure, as described here for Strep. uberis, are particularly useful when information on the causative agent is available. Several studies have demonstrated the feasibility of using on-farm diagnostics to inform case management (Lago et al., 2011; Cameron et al., 2014), and additional tests for rapid or on-farm screening of milk samples are under development, including culture and DNA-based tests (Viora et al., 2014; Bosward et al., 2016). Considering the similarities between results obtained for Strep. uberis and Staph. aureus, some of this information may also be of value in the absence of an etiological diagnosis, although further field evaluation will be needed to validate such a generic approach.

Increased parity was associated with a reduced likelihood of cure. This finding was not merely a reflection of the chronicity of infection, because parity was significant after correction for SCC, which is a proxy for duration (Barkema et al., 2006). The mechanism behind the reduced probability of cure in older animals is unknown. Possible explanations were discussed by Barkema et al. (2006) for the response to treatment of Staph. aureus IMI. One potential explanation is the change in ratio between udder volume, which increases with age, and the administered dose of antimicrobials, which is independent of age, resulting in a lower dose per unit udder volume in older animals (Barkema et al., 2006). This reasoning would also apply to Strep. uberis treatment. Immunosenescence, the waning of the immune response with age, could be postulated to play a role in the deterioration of treatment outcome with age, but no specific evidence for this is available in the context of bovine mastitis. Regardless of the underlying mechanism, the comparatively poor treatment response of older cows can be interpreted as an imperative to help cows age healthily, such as by selecting for cows with high genetic merit for udder health or immune responsiveness (Thompson-Crispi et al., 2014). In addition, animal-level risk factors should be minimized where possible. For example, severe teat end hyperkeratosis is an animal-level risk factor for Strep. uberis $\mathrm{CM}$, and the risk of hyperkeratosis can be reduced by avoiding overmilking (Breen et al., 2009; Edwards et al., 2013).

The observation that duration of IMI, as measured by the number of elevated monthly SCC before treatment, is predictive of cure is compatible with previous data on both Strep. uberis and Staph. aureus. A detailed longitudinal study of Strep. uberis IMI in 2 herds showed that some episodes of $\mathrm{CM}$ were due to recent IMI and other CM episodes were preceded by periods of elevated SCC (Zadoks et al., 2003). Clinical manifestation episodes without preceding SCC elevation were more likely to be followed by cure than $\mathrm{CM}$ episodes with preceding SCC elevation. Similarly, in several treatment trials of Staph. aureus IMI, higher or longer SCC elevation before treatment was associated with a decreased probability of cure (Barkema et al., 2006). A poor response of chronic Staph. aureus IMI to treatment may be explained in part by micro-abscess formation and fibrosis (Erskine et al., 2003). Fibrosis also occurs during Strep. uberis mastitis, starting as early as $6 \mathrm{~d}$ after infection in experimental challenge studies. It is accompanied by presence of the pathogen in subepithelial and septal tissue, and in lymphatic vessels and lymph nodes (Thomas et al., 1994). This may explain why the response of Strep. uberis mastitis to treatment can be poor, even after extended therapy (Milne et al., 2005). In both experimentally induced and persistent Strep. uberis IMI, extended therapy increases the probability of cure (Oliver et al., 2003; Swinkels et al., 2014). The benefits of extended therapy must be weighed against its disadvantages, including the increased costs of antibiotics and milk discard, and the increased risk of residue in milk and selection for antimicrobial resistance (Hillerton and Kliem, 2002; Barkema et al., 2006). As in any risk factor study, the risk factors identified in the current study (including treatment modality) and their coefficients allow us to quantify the increase or decrease in likelihood of a particular treatment outcome, but a specific outcome in any individual animal cannot be predicted.

In the current study, a numerical but nonsignificant increase in cure was observed with an increase in treatment modalities (intramammary and parenteral antimicrobials and NSAIDs). This study was not, however, a randomized controlled clinical trial, nor was it meant to be. Farmers tended to treat severe cases of mastitis with a combination of intramammary, parenteral, 
and antiinflammatory products; first clinical cases with intramammary treatment only; and repeated and subclinical cases with antimicrobial treatment by both the intramammary and parenteral routes. This implies that farmers are aware of the usefulness of cow-specific treatment, with consideration of both animal welfare and the economic aspects of treatment. This information provides evidence that farmers are willing to make cow-specific decisions and bodes well for the feasibility of including cow-specific risk factors in future protocols. In our practice, farm-specific treatment protocols are already discussed with each farmer on an annual basis, and the treatment choices reported by the farmers are in line with those protocols. As a next step toward judicious use of antimicrobials, we envisage implementation of cow-specific protocols.

Animals with short-duration mastitis (no or single SCC elevation before diagnosis) were likely to cure (no or single SCC elevation after diagnosis), whereas animals with long-duration mastitis (multiple SCC elevations before diagnosis) were likely not to cure (multiple SCC elevations after diagnosis). Similarly, data availability after diagnosis mirrored data availability before diagnosis: animals with incomplete SCC data before diagnosis often had incomplete SCC data after diagnosis too (data not shown). This would apply mostly to animals in early lactation that were lost to follow-up due to culling. Thus, although our analysis shows no significant difference in cure between different severity classes, this result is affected by "healthy worker bias," whereby only surviving cows were included in the analysis. Indeed, loss to follow-up as indicated by the absence of data on cure was proportionally higher for severe cases than for non-severe cases (Table 1).

Of the herd-level factors considered in this study, use of PostMTD was associated with a reduced risk of severe, repeat, and subclinical Strep. uberis mastitis compared with first cases of mastitis. The value of PostMTD in reducing the risk of Strep. uberis IMI has been documented repeatedly (Zadoks et al., 2003; Galton, 2004; Williamson and Lacy-Hulbert, 2013) but it has not been linked to clinical manifestation. Strain-specific transmission and virulence patterns have previously been suggested or documented (Zadoks et al., 2003; Tassi et al., 2013) and could theoretically contribute to an association between PostMTD and clinical manifestation. It has also been hypothesized that host immune status may contribute to CM of Strep. uberis IMI (Tassi et al., 2013). Indeed, in the current study, severe cases of CM were overrepresented among heifers and animals in early lactation. This emphasizes the importance of another herd-level management factor: adequate care of nonlactating animals. Considering that Strep. uberis is common in the feces and environment of cattle (Zadoks et al., 2005), environmental hygiene is of particular importance. The risk of infection in heifers and dry cows can also be reduced through use of teat spray and internal teat sealants (Lopez-Benavides et al., 2009; Compton et al., 2014). With increasing pressure to reduce antimicrobial use, implementation of nonantimicrobial mastitis prevention measures becomes increasingly important.

In this field study, definitions of transient and persistent IMI and cure were based on SCC data. Although repeated posttreatment culture has been considered the "gold standard" for cure in clinical trials, additional or alternative metrics for cure are increasingly reported in field studies. SCC has been used as a primary criterion for cure in studies of CM, subclinical mastitis, and dry cow treatment (St. Rose et al., 2003; Lago et al., 2011; Persson et al., 2015). Somatic cell count is routinely used as an indicator of infection status (Schukken et al., 2003), although the probability of bacteriological cure is higher than the probability of SCC-based cure in studies of chronic streptococcal mastitis (St. Rose et al., 2003). Somatic cell count is of immediate interest to farmers, unlike bacteriological cure, which is primarily of academic interest. Moreover, SCC is routinely available at very low cost, which makes its large-scale use feasible in field studies, veterinary practice, and farm management. Finally, SCC captures long-term outcomes of mastitis treatment, whereas culture results generally only reflect the first few weeks posttreatment. Thus, SCC is a convenient, affordable, and meaningful indicator of treatment outcome.

\section{CONCLUSIONS}

Treatment recommendations can be informed by animal-level data that is routinely available to farmers and veterinarians, such as parity and SCC. To some extent, treatment recommendations can be animal-specific rather than pathogen-specific, as both Strep. uberis IMI and Staph. aureus IMI show a better response to treatment in animals in first or second lactation and in animals with a single high SCC value than in older animals or animals with multiple high SCC values before treatment. In older animals or animals with multiple high SCC values, the simultaneous use of multiple treatment modalities may enhance the probability of cure but would result in increased use of antimicrobials. To limit the need for such treatment, continued or renewed emphasis on herd management and infection prevention is needed. Formal validation of the observations described here through a randomized controlled clinical trial may strengthen the evidence base underpinning 
the suggested treatment decisions. In the absence of such validation, the evidence presented here is the best available for informing decisions on treatment of Strep. uberis mastitis, the most common type of mastitis observed in this and many other studies.

\section{ACKNOWLEDGMENTS}

This research was financed by Vetformance Veterinary Services, France. The authors thank all participating veterinarians and farmers from Vetformance, the "Clinique Vétérinaire de Tinchebray," and the "Clinique Vétérinaire de Guerche de Bretagne."

\section{REFERENCES}

Barkema, H. W., Y. H. Schukken, T. J. Lam, M. L. Beiboer, G. Benedictus, and A. Brand. 1999. Management practices associated with the incidence rate of clinical mastitis. J. Dairy Sci. 82:1643-1654.

Barkema, H. W., Y. H. Schukken, and R. N. Zadoks. 2006. Invited review: The role of cow, pathogen, and treatment regimen in the therapeutic success of bovine Staphylococcus aureus mastitis. J. Dairy Sci. 89:1877-1895.

Bosward, K. L., J. K. House, A. Deveridge, K. Mathews, and P. A. Sheehy. 2016. Development of a loop-mediated isothermal amplification assay for the detection of Streptococcus agalactiae in bovine milk. J. Dairy Sci. 99:2142-2150.

Bradley, A. J., K. A. Leach, J. E. Breen, L. E. Green, and M. J. Green 2007. Survey of the incidence and aetiology of mastitis on dairy farms in England and Wales. Vet. Rec. 160:253-257.

Breen, J. E., M. J. Green, and A. J. Bradley. 2009. Quarter and cow risk factors associated with the occurrence of clinical mastitis in dairy cows in the United Kingdom. J. Dairy Sci. 92:2551-2561.

Cameron, M., S. L. McKenna, K. A. MacDonald, I. R. Dohoo, J. P. Roy, and G. P. Keefe. 2014. Evaluation of selective dry cow treatment following on-farm culture: Risk of postcalving intramammary infection and clinical mastitis in the subsequent lactation. J. Dairy Sci. 97:270-284.

Compton, C. W., F. R. Emslie, and S. McDougall. 2014. Randomised controlled trials demonstrate efficacy of a novel internal teat sealant to prevent new intramammary infections in dairy cows and heifers. N. Z. Vet. J. 62:258-266.

Edwards, J. P., B. O'Brien, N. Lopez-Villalobos, and J. G. Jago. 2013 Overmilking causes deterioration in teat-end condition of dairy cows in late lactation. J. Dairy Res. 80:344-348.

Ericsson Unnerstad, H., A. Lindberg, K. Persson Waller, T. Ekman, K. Artursson, M. Nilsson-Ost, and B. Bengtsson. 2009. Microbial aetiology of acute clinical mastitis and agent-specific risk factors. Vet. Microbiol. 137:90-97.

Erskine, R. J., S. Wagner, and F. J. DeGraves. 2003. Mastitis therapy and pharmacology. Vet. Clin. North Am. Food Anim. Pract. 19:109-138.

Galton, D. M. 2004. Effects of an automatic postmilking teat dipping system on new intramammary infections and iodine in milk. J. Dairy Sci. 87:225-231.

Hillerton, J. E., and K. E. Kliem. 2002. Effective treatment of Streptococcus uberis clinical mastitis to minimize the use of antibiotics. J. Dairy Sci. 85:1009-1014.

Hosmer, D. W., and S. Lemeshow. 2013. Applied Logistic Regression. Wiley, New York, NY.

Jones, P. J., E. A. Marier, R. B. Tranter, G. Wu, E. Watson, and C J. Teale. 2015. Factors affecting dairy farmers' attitudes towards antimicrobial medicine usage in cattle in England and Wales. Prev. Vet. Med. 121:30-40.
Lago, A., S. M. Godden, R. Bey, P. L. Ruegg, and K. Leslie. 2011 The selective treatment of clinical mastitis based on on-farm culture results: II. Effects on lactation performance, including clinical mastitis recurrence, somatic cell count, milk production, and cow survival. J. Dairy Sci. 94:4457-4467.

Lopez-Benavides, M. G., J. H. Williamson, S. J. Lacy-Hulbert, and R. T. Cursons. 2009. Heifer teats sprayed in the dry period with an iodine teat sanitizer have reduced Streptococcus uberis teat-end contamination and less Streptococcus uberis intra-mammary infections at calving. Vet. Microbiol. 134:186-191.

Makovec, J. A., and P. L. Ruegg. 2003. Antimicrobial resistance of bacteria isolated from dairy cow milk samples submitted for bacterial culture: 8,905 samples (1994-2001). J. Am. Vet. Med. Assoc. $222: 1582-1589$

Milne, M. H., A. M. Biggs, D. C. Barrett, F. J. Young, S. Doherty, G. T. Innocent, and J. L. Fitzpatrick. 2005. Treatment of persistent intramammary infections with Streptococcus uberis in dairy cows. Vet. Rec. 157:245-250.

Nam, H. M., S. K. Lim, J. S. Moon, H. M. Kang, J. M. Kim, K. C. Jang, J. M. Kim, M. I. Kang, Y. S. Joo, and S. C. Jung. 2010. Antimicrobial resistance of enterococci isolated from mastitic bovine milk samples in Korea. Zoonoses Public Health 57:e59-e64.

National Mastitis Council. 1999. Laboratory Handbook on Bovine Mastitis. National Mastitis Council, Madison, WI.

Olde Riekerink, R. G., H. W. Barkema, D. F. Kelton, and D. T. Scholl 2008. Incidence rate of clinical mastitis on Canadian dairy farms. J. Dairy Sci. 91:1366-1377.

Oliver, S. P., R. A. Almeida, B. E. Gillespie, S. J. Ivey, H. Moorehead, P. Lunn, H. H. Dowlen, D. L. Johnson, and K. C. Lamar. 2003 Efficacy of extended pirlimycin therapy for treatment of experimentally induced Streptococcus uberis intramammary infections in lactating dairy cattle. Vet. Ther. 4:299-308.

Persson, Y., J. Katholm, H. Landin, and M. J. Mörk. 2015. Efficacy of enrofloxacin for the treatment of acute clinical mastitis caused by Escherichia coli in dairy cows. Vet. Rec. 176:673.

Petrovski, K. R., N. B. Williamson, N. Lopez-Villalobos, T. J. Parkinson, and I. G. Tucker. 2011. Culture results from milk samples submitted to veterinary diagnostic laboratories from August 2003 to December 2006 in New Zealand. N. Z. Vet. J. 59:317-322.

Pol, M., and P. Ruegg. 2007. Treatment practices and quantification of antimicrobial drug usage in conventional and organic dairy farms in Wisconsin. J. Dairy Sci. 90:249-261.

Raymond, M. J., R. D. Wohrle, and D. R. Call. 2006. Assessment and promotion of judicious antibiotic use on dairy farms in Washington State. J. Dairy Sci. 89:3228-3240.

Sampimon, O., H. W. Barkema, I. Berends, J. Sol, and T. Lam. 2009. Prevalence of intramammary infection in Dutch dairy herds. J. Dairy Res. 76:129-136.

Scherpenzeel, C. G., I. E. den Uijl, G. van Schaik, R. G. Olde Riekerink, J. M. Keurentjes, and T. J. Lam. 2014. Evaluation of the use of dry cow antibiotics in low somatic cell count cows. J. Dairy Sci. 97:3606-3614

Schukken, Y. H., D. J. Wilson, F. Welcome, L. Garrison-Tikofsky, and R. N. González. 2003. Monitoring udder health and milk quality using somatic cell counts. Vet. Res. 34:579-596.

Soussy, C. J. 2013. Recommendations 2013: Communique du Comité de l'antibiogramme de la Société Française de Microbiologie. Institut Pasteur, Paris, France.

St Rose, S. G., J. M. Swinkels, W. D. Kremer, C. L. Kruitwagen, and R. N. Zadoks. 2003. Effect of penethamate hydriodide treatment on bacteriological cure, somatic cell count and milk production of cows and quarters with chronic subclinical Streptococcus uberis or Streptococcus dysgalactiae infection. J. Dairy Res. 70:387-394.

Swinkels, J. M., V. Krömker, and T. J. Lam. 2014. Efficacy of standard vs. extended intramammary cefquinome treatment of clinical mastitis in cows with persistent high somatic cell counts. J. Dairy Res. 81:424-433.

Tassi, R., N. McNeilly, J. L. Fitzpatrick, M. C. Fontaine, D. Reddick, C. Ramage, M. Lutton, Y. H. Schukken, and R. N. Zadoks. 2013 Strain-specific pathogenicity of putative host-adapted and non- 
adapted strains of Streptococcus uberis in dairy cattle. J. Dairy Sci. 96:5129-5145.

Thomas, L. H., W. Haider, A. W. Hill, and R. S. Cook. 1994. Pathologic findings of experimentally induced Streptococcus uberis infection in the mammary gland of cows. Am. J. Vet. Res. 55:1723-1728.

Thompson-Crispi, K., H. Atalla, F. Miglior, and B. A. Mallard. 2014. Bovine mastitis: Frontiers in immunogenetics. Front. Immunol. 5:493.

UK Department of Health. 2013. UK five-year antimicrobial resistance strategy 2013 to 2018. Accessed Oct. 18, 2015. http://www.gov. $\mathrm{uk} / \mathrm{dh}$.

Verbeke, J., S. Piepers, K. Supré, and S. De Vliegher. 2014. Pathogenspecific incidence rate of clinical mastitis in Flemish dairy herds, severity, and association with herd hygiene. J. Dairy Sci. 94:69266934.

Viora, L., E. M. Graham, D. J. Mellor, K. Reynolds, P. B. Simoes, and T. E. Geraghty. 2014. Evaluation of a culture-based pathogen identification kit for bacterial causes of bovine mastitis. Vet. Rec. 175:89.

Williamson, J. H., and S. J. Lacy-Hulbert. 2013. Effect of disinfecting teats post-milking or pre- and post-milking on intramammary infection and somatic cell count. N. Z. Vet. J. 61:262-268.
World Health Organization. 2015. World Health Assembly addresses antimicrobial resistance, immunization gaps and malnutrition. Accessed Oct. 18, 2015. http://www.who.int/mediacentre/news/ releases/2015/wha-25-may-2015/en/.

Zadoks, R. N. 2007. Sources and epidemiology of Streptococcus uberis, with special emphasis on mastitis in dairy cattle. CAB Rev. 2:1-15.

Zadoks, R. N., H. G. Allore, H. W. Barkema, O. C. Sampimon, G. J. Wellenberg, Y. T. Gröhn, and Y. H. Schukken. 2001. Cow- and quarter-level risk factors for Streptococcus uberis and Staphylococcus aureus mastitis. J. Dairy Sci. 84:2649-2663.

Zadoks, R. N., B. E. Gillespie, H. W. Barkema, O. C. Sampimon, S. P. Oliver, and Y. H. Schukken. 2003. Clinical, epidemiological and molecular characteristics of Streptococcus uberis infections in dairy herds. Epidemiol. Infect. 130:335-349.

Zadoks, R. N., L. L. Tikofsky, and K. J. Boor. 2005. Ribotyping of Streptococcus uberis from a dairy's environment, bovine feces and milk. Vet. Microbiol. 109:257-265. 